\title{
LPS-Induced Inflammation Potentiates the IL-1 $\beta$-Mediated Reduction of LH Secretion from the Anterior Pituitary Explants
}

\author{
Andrzej Przemysław Herman, ${ }^{1}$ Agata Krawczyńska, ${ }^{1}$ Joanna Bochenek, ${ }^{1}$ Elżbieta Dobek, \\ Anna Herman, ${ }^{2}$ and Dorota Tomaszewska-Zaremba ${ }^{1}$ \\ ${ }^{1}$ Polish Academy of Sciences, The Kielanowski Institute of Animal Physiology and Nutrition, 05-110 Jabłonna, Poland \\ ${ }^{2}$ The Academy of Cosmetics and Health Care, 13 Podwale Street, 00-252 Warsaw, Poland \\ Correspondence should be addressed to Andrzej Przemysław Herman; a.herman@ifzz.pan.pl
}

Received 9 May 2013; Revised 20 June 2013; Accepted 2 July 2013

Academic Editor: Carlos Barcia

Copyright (C) 2013 Andrzej Przemysław Herman et al. This is an open access article distributed under the Creative Commons Attribution License, which permits unrestricted use, distribution, and reproduction in any medium, provided the original work is properly cited.

\begin{abstract}
Acting at the level of the brain, interleukin- (IL-) $1 \beta$ is considered to be one of the most potent downregulators of reproduction processes during immune/inflammatory challenge. IL- $1 \beta$ suppresses gonadotropin-releasing hormone (GnRH) secretion from the hypothalamus resulting in the inhibition of the luteinizing hormone (LH) release from the anterior pituitary (AP). However, the presence of IL- $1 \beta$ receptors in the AP suggests the possible direct action of this cytokine on LH secretion. The study was designed to determine the effect of IL- $1 \beta$ on the LH secretion from the AP explants collected from saline and LPS-treated ewes in the follicular phase. It was found that IL- $1 \beta$ suppressed $(P \leq 0.01) \mathrm{GnRH}$-stimulated LH release and LH $\beta$ gene expression in AP explants in both groups. However, IL-1 $\beta$ action was more potent in the explants collected from LPS-treated animals. Pituitaries from LPS-treated animals were characterized by increased $(P \leq 0.01)$ IL-1 type I receptor and decreased $(P \leq 0.01)$ GnRH receptor gene expression level compared to the saline-treated group. IL-1 $\beta$ also affected the GnRH-R gene expression in explants collected from LPS-treated animals. Our results show that direct action of IL-1 $\beta$ on the pituitary gonadotropes could be one of the reasons of the reproductive processes disorders accompanying an inflammatory state.
\end{abstract}

\section{Introduction}

An immune/inflammatory challenge is considered as an important factor inhibiting the reproduction process in animals and human. The inflammation caused by peripheral administration of bacterial endotoxin-lipopolysaccharide (LPS) significantly decreases gonadotropin-releasing hormone $(\mathrm{GnRH})$ and luteinizing hormone $(\mathrm{LH})$ secretion [13]. These interconnections existing between the immune and the neuroendocrine systems are based on the mutual sharing of receptors and mediators [4]. Numerous in vitro and in vivo studies showed that the immune stress affects the GnRH/LH secretion by the central action of proinflammatory cytokines affecting the secretory activity of $\mathrm{GnRH}$ neurons in the hypothalamus [4-6]. One of the most potent and pleiotropic cytokines of the immune system is interleukin- (IL-)1 $\beta$ [7]. Its action at the level of the hypothalamus is considered as an important mechanism via inflammation downregulates GnRH/LH secretion [8-10]. However, the presence of IL-1 type I receptor (IL-1R1) in the pituitary $[11,12]$ suggests that antigonadotropic action of IL- $1 \beta$ could be more complex and may occur also at the level of this gland.

The present study was designed to determine the effect of IL- $1 \beta$ on the LH secretion from the anterior pituitary (AP) explants. Conducting ex vivo experiment on the pituitary explants instead of more popular primary cell culture lets us better imitate the reaction of AP under ex vivo conditions, because without dispersion the AP cells preserved many of their intercellular connections. Moreover, in the present studies, the pituitary explants were collected form saline and LPS-treated ewes. This should allow answering the questions whether the pituitaries kept their "memory" of the events triggered by LPS exposure and if that "immunological" status of animals can modulate the pituitary response on IL-1 $\beta$. 


\section{Materials and Methods}

2.1. Animals. The studies were performed on 3-year-old Blackhead ewes during the reproductive season (SeptemberOctober). The animals were maintained indoors in individual pens and exposed to natural daylight. All ewes were healthy; their condition was continuously monitored by a qualified veterinarian. The ewes were well adapted to the experimental conditions and always had visual contact with neighbouring ewes, even during the experimental period, to prevent stress due to social isolation. The animals were fed a constant diet of commercial concentrates with hay and water available ad libitum.

The ewes were synchronized by Chronogest CR method (Merck Animal Health, Boxmeer, The Netherlands) using an intravaginal sponge impregnated with $20 \mathrm{mg}$ of synthetic progesterone-like hormone. All ewes had Chronogest CR sponges placed for 14 days. Following sponge removal, the ewes received an intramuscular injection of 500 iu pregnant mare's serum gonadotropin (PMCS) (Merck Animal Health, Boxmeer, The Netherlands). The experimental procedure was started $24 \mathrm{~h}$ following PMSG injection.

All procedures on animals were performed with the consent of the Local Ethics Committee of the Warsaw Agricultural University.

\section{Experimental Procedures}

3.1. Inducing Immune Stress in the Experimental Animals. Ewes $(n=12)$ were randomly assigned to two experimental groups: control $(n=6)$ and LPS-treated groups $(n=6)$. In treated ewes, an innate immune system response was activated by injection of LPS ( $400 \mathrm{ng} / \mathrm{kg}$ of body weight) from E. coli 055:B5 (Sigma-Aldrich, St. Louis, MO, USA) dissolved in saline $(0.9 \% \mathrm{w} / \mathrm{v} \mathrm{NaCl})$ (Baxter, Deerfield, IL, USA) at a concentration of $10 \mathrm{mg} / \mathrm{L}$ intravenously (i.v.) into jugular vein. The maximum volume of LPS solution $(10 \mathrm{mg} / \mathrm{L})$ injected to any animals never exceeds $2.5 \mathrm{~mL}$. The control group received an equivalent to their body weight volume of $\mathrm{NaCl}$.

3.2. Incubation of the AP Explants Ex Vivo. The animals from both groups were slaughtered by decapitation 2 hours after i.v. injection of LPS $(n=6)$ or saline $(n=6)$. The ovine brains were rapidly removed from the skulls and the APs were dissected. Immediately after slaughtering, the APs were divided into four fragments weighing from 50 to $60 \mathrm{mg}$ which were transferred to 24-well plates (Becton Dickinson Labware, Franklin Lakes, NJ, USA). The ex vivo incubation of the explants was performed in medium 199 HEPES Modification (Sigma-Aldrich, St. Louis, MO, USA) suitable for cell culture with Penicillin-Streptomycin at the dose of $10 \mathrm{~mL} / \mathrm{L}$ (Sigma-Aldrich, St. Louis, MO, USA) and incubated at $37^{\circ} \mathrm{C}, 87 \% \mathrm{O}_{2}$, and $5 \% \mathrm{CO}_{2}$. After the collection, all the tissues were preincubated for $1 \mathrm{~h}$ in $800 \mu \mathrm{L}$ of "pure" medium 199. During preincubation, the medium was changed for the fresh one four times every $15 \mathrm{~min}$. The preincubation was performed to wash out blood and hormones remains from pituitary fragments. Then, the explants collected from each saline as well as LPS-treated ewe were divided into four experimental groups as follows: control-AP explants $(n=$ 6) incubated in $600 \mu \mathrm{L}$ of medium 199; GnRH control-AP explants $(n=6)$ incubated in $600 \mu \mathrm{L}$ of medium 199 with $\mathrm{GnRH}(100 \mathrm{pmol} / \mathrm{mL})$ (Sigma-Aldrich, St. Louis, MO, USA); IL- $1 \beta$-AP explants $(n=6)$ incubated in $600 \mu \mathrm{L}$ of medium 199 with IL-1 $\beta$ (100 pg/mL) (Sigma-Aldrich, St. Louis, MO, USA); GnRH + IL-1 $\beta$-AP explants $(n=6)$ incubated in $600 \mu \mathrm{L}$ of medium 199 with $\mathrm{GnRH}(100 \mathrm{pmol} / \mathrm{mL})$; and IL$1 \beta(100 \mathrm{pg} / \mathrm{mL})$. The ex vivo experiment was carried out for $4 \mathrm{~h}$. During $1 \mathrm{~h}$ of incubation, all explants were treated with $600 \mu \mathrm{L}$ of "pure" medium 199. The medium was changed to fresh three times every $20 \mathrm{~min}$. After $1 \mathrm{~h}$, all the AP explants were incubated in the experimental medium appropriate to each experimental group. The media were changed every $20 \mathrm{~min}$ for the fresh one and $600 \mu \mathrm{L}$ samples were collected. The dose of treatments, condition of incubation, and time of the experiment were previously optimized in the preliminary studies. After finished incubation, all tissues were frozen in liquid nitrogen and stored at $-80^{\circ} \mathrm{C}$ until assay.

\section{Assays}

4.1. Radioimmunoassay for $L H$. The concentration of $\mathrm{LH}$ in medium was assayed by the RIA double antibody method using anti-ovine-LH and anti-rabbit- $\gamma$-globulin antisera and ovine standard (NIH-LH-SO18) as described by Stupnicki and Madej [13]. The sensitivity was $0.3 \mathrm{ng} / \mathrm{mL}$, and intraassay and interassay coefficients of variation were $8.9 \%$ and $12.3 \%$, respectively.

4.2. The Relative Gene Expression Assay. Total RNA from the AP tissues was isolated using NucleoSpin RNA II Kit (MACHEREY-NAGEL Gmbh and Co.; Düren, Germany) according to the manufacturer's instruction. The purity and concentration of isolated RNA were quantified spectrophotometrically by measuring the optical density at 230, 260, and $280 \mathrm{~nm}$ in a NanoDrop 1000 instrument (Thermo Fisher Scientific Inc., Waltham, USA). The RNA integrity was verified by electrophoresis using $1 \%$ agarose gel stained with ethidium bromide. Maxima First Strand cDNA Synthesis Kit for RT-qPCR (Thermo Fisher Scientific Inc., Waltham, USA) was used to prepare cDNA synthesis. As a starting material for this PCR synthesis, $2 \mu \mathrm{g}$ of total RNA was used.

Real-time RT-PCR was carried out using HOT FIREPol EvaGreen qPCR Mix Plus (Solis BioDyne, Tartu, Estonia) components and HPLC-grade oligonucleotide primers synthesised by Genomed (Poland). Specific primers for determining the expression of housekeeping genes and the genes of interest were designed using Primer 3 software. The sequences of the primers were as follows: $\mathrm{LH} \beta$ primers: $5^{\prime}$-AGATGCTCCAGGGACTGCT-3' (forward) and $5^{\prime}$-TGCTTCATGCTGAGGCAGTA-3' (reverse) (GenBank accession no. X52488), generated product size 184bp; GnRH-R primers: $5^{\prime}$-TCTTTGCTGGACCACAGTTAT$3^{\prime}$ (forward) and $5^{\prime}$-GGCAGCTGAAGGTGAAAAAG-3' 
(reverse) (GenBank accession no. NM-001009397), generated product size 150-bp; IL-1 receptor type I primers: $5^{\prime}$ GAGGAAGACTTTATCACAGTGGA- $3^{\prime}$ (forward) and $5^{\prime}$ GGCTAAACAGGTAAATGGATGC-3' (reverse) (GenBank accession no. NM_001206735.1), generated product size 120bp; $\beta$-actin (ACTB) primers: $5^{\prime}$-CTTCCTTCCTGGGCATGG-3' (forward) and $5^{\prime}$-GGGCAGTGATCTCTTTCTGC$3^{\prime}$ (reverse) (GenBank accession no. U39357), generated product size 168-bp; glyceraldehyde-3-phosphate dehydrogenase (GAPDH) primers: $5^{\prime}$-AGAAGGCTGGGGCTCACT$3^{\prime}$ (forward) and $5^{\prime}$-GGCATTGCTGACAATCTTGA- $3^{\prime}$ (reverse) (GenBank accession no. NM-001034034), generated product size 134-bp; cyclophilin C (PPIC) primers: $5^{\prime}$ ACGGCCAAGGTCTTCTTTG-3' (forward) and $5^{\prime}$-TATCCTTTCTCTCCCGTTGC-3' (reverse) (GenBank accession no. NM-001076910), generated product size 131-bp. One tube contained $4 \mu \mathrm{L}$ PCR Master Mix (5x), $14 \mu \mathrm{L}$ RNase-free water, $1 \mu \mathrm{L}$ primers $(0.5 \mu \mathrm{L}$ each, working concentration was $0.25 \mu \mathrm{M})$, and $1 \mu \mathrm{L} \mathrm{cDNA}$ template. The tubes were run on the Rotor-Gene 6000 (Qiagen, Duesseldorf, Germany). The following protocol was used: $95^{\circ} \mathrm{C}$ in $15 \mathrm{~min}$ for activating Hot Start DNA polymerase and finally the PCR including 30 cycles at $95^{\circ} \mathrm{C}$ in $10 \mathrm{sec}$ for denaturation, $60^{\circ} \mathrm{C}$ in $20 \mathrm{sec}$ for annealing, and $72^{\circ} \mathrm{C}$ in $10 \mathrm{sec}$ for extension. After the cycles, a final melting curve analysis under continuous fluorescence measurements was performed to confirm the specificity of the amplification.

\section{Data Analysis}

5.1. LH Concentration Data Analysis. The results of LPS treatments on the concentrations of LH in all types of mediums were examined by two-way analysis of variance (ANOVA) (STATISTICA; Stat-Soft, Inc., Tulsa, OK, USA). The least significant differences post hoc test was used for the comparison of LH concentration between the 20 min periods of the ex vivo experiment within and between the groups. The Mann-Whitney $U$ test was used to compare these values. All data are expressed as means \pm SEM. Statistical significance was defined as $P \leq 0.01$.

5.2. PCR Data Analysis. Relative gene expression was calculated using the comparative quantification option of Rotor Gene 6000 software 1.7. (Qiagen, Duesseldorf, Germany). The second differential maximum method [14] was used in this analysis to calculate reaction efficiencies and a set percentage of the maximum fluorescence value to calculate the beginning of the exponential phase. To compensate a variation in cDNA concentrations and the PCR efficiency between tubes, an endogenous control gene was assayed in each sample and used for normalization. Initially, three housekeeping genes: GAPDH, $\beta$-actin, and PPIC were tested. The BestKeeper was used to determine the most stable housekeeping gene, for normalizing genes of interest expression. The BestKeeper is based on the pairwise correlation analysis of all pairs of candidate genes [15] and calculates variations of all reference genes $(\mathrm{SD}( \pm \mathrm{Ct}))$. GAPDH was chosen as the best endogenous control gene. They had the lowest $\mathrm{SD}( \pm \mathrm{Ct})$ value and
TABLE 1: Summary release of LH from the AP explants collected from saline and LPS-treated ewes during the $3 \mathrm{~h}$ incubation period.

\begin{tabular}{lcc}
\hline \multirow{2}{*}{ Group } & \multicolumn{2}{c}{ Concentration of LH (ng/mg) } \\
& Saline treated & LPS treated \\
\hline Control & $15.8 \pm 3.6$ & $18.5 \pm 5.3$ \\
GnRH control & $43.5 \pm 4.1^{\mathrm{a}}$ & $48.5 \pm 4.6^{\mathrm{e}}$ \\
$\mathrm{IL}-1 \beta$ & $14.8 \pm 3.2$ & $19.3 \pm 4.1$ \\
$\mathrm{IL}-1 \beta+\mathrm{GnRH}$ & $31.2 \pm 3.0^{\mathrm{abc}}$ & $21.0 \pm 3.4^{\mathrm{df}}$ \\
\hline $\mathrm{a}, \mathrm{b}, \mathrm{c}, \mathrm{d}$ & ${ }_{P} \leq 0.01$ (indicating values that differ significantly from the control,
\end{tabular}
GnRH control, IL-1 $\beta$, and IL- $1 \beta+$ GnRH groups of saline-treated explants, respectively, according to the Mann-Whitney $U$-test).

${ }^{e, f} P \leq 0.01$ (indicating values that differ significantly from the control and GnRH control groups of LPS-treated explants, respectively, according to the Mann-Whitney $U$-test).

Data are presented as a median value \pm SEM.

a good correlation coefficient with the remaining analyzed housekeeping genes.

The results are presented as relative gene expression of the target gene versus housekeeping gene, relative expression value, and median \pm SEM. The significance of differences between the experimental groups was assessed by the MannWhitney $U$ test. Statistical significance was defined as $P \leq$ 0.01 .

\section{Results}

6.1. The Ex Vivo Effect of IL-1 3 on the LH Release. In the explants collected from saline and LPS-treated ewes, the GnRH significantly $(P \leq 0.01)$ stimulated LH release, and there were no important differences in their response to GnRH (Figure 1). IL-1 $\beta$ lowered $(P \leq 0.01)$ GnRH-induced release of LH both in saline- and LPS-treated groups (Table 1). However, LPS-induced inflammation potentiated the IL- $1 \beta$ mediated reduction of LH secretion from the AP explants. The effect of IL- $1 \beta$ was stronger $(P \leq 0.01)$ in organs collected from LPS-treated ewes where the GnRH-induced rise of LH was completely abolished than in explants from salineinjected ewes where temporary increase in the release of $\mathrm{LH}$ was observed (Figure 1).

6.2. Effect of IL-1 $\beta$ on $L H-\beta, G n R H-R$, and IL-1R1 Gene Expressions in the AP Explants. In the AP explants collected from saline-treated ewes, GnRH $(P \leq 0.01)$ stimulated LH- $\beta$ gene expression (median exp. $1.25 \pm 0.08$ ) compared to the control group (median exp. $1 \pm 0.09$ ). On the other hand, IL-1 $\beta$ decreased $(P \leq 0.01)$ the level of LH- $\beta$ mRNA when added alone (median exp. $0.72 \pm 0.17$ ) and together with GnRH (median exp. $0.81 \pm 0.06$ ) compared to both controland GnRH-treated groups. In AP explants collected from LPS-treated animals, GnRH also $(P \leq 0.01)$ stimulated LH- $\beta$ gene expression (median exp. $1.69 \pm 0.18$ ) compared to the control group (median exp. $1.12 \pm 0.09$ ). However, IL-1 $\beta$ prevented the GnRH-induced increase of $\mathrm{LH} \beta$ gene expression (Figure 2). There was no effect of GnRH on its receptor gene expression in AP explants. However, GnRH$\mathrm{R}$ mRNA level was lower $(P \leq 0.01)$ in APs collected from 


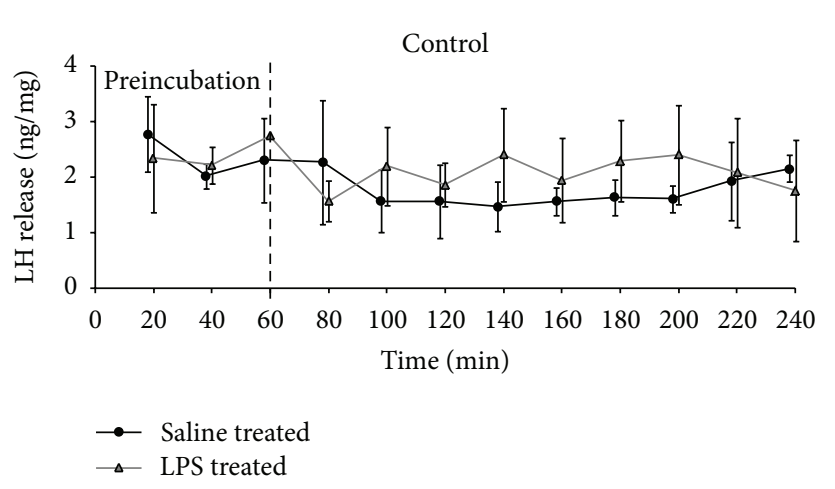

(a)

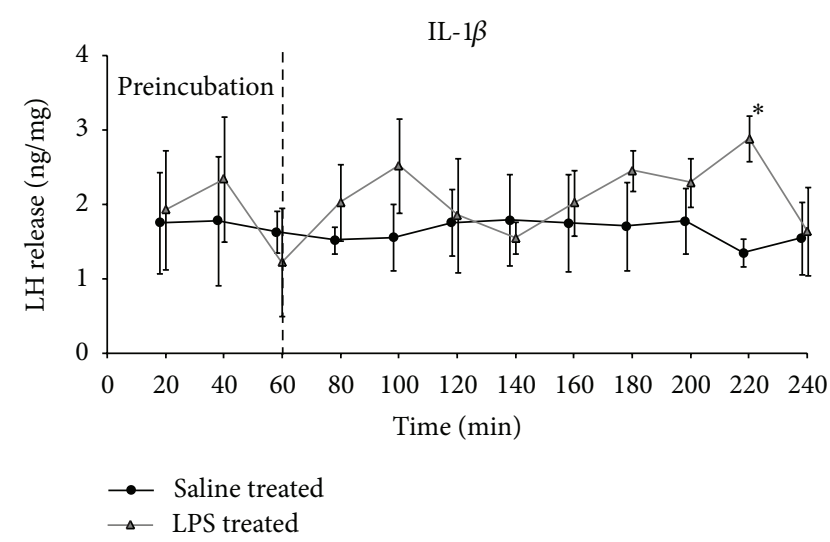

(c)

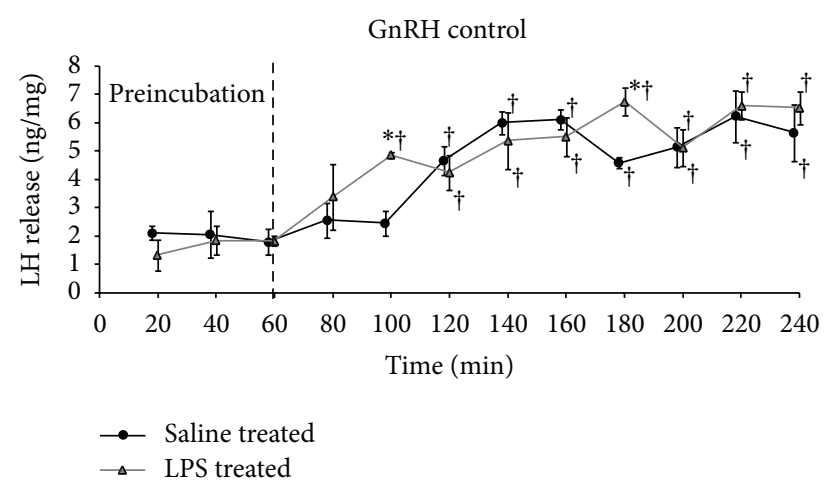

(b)

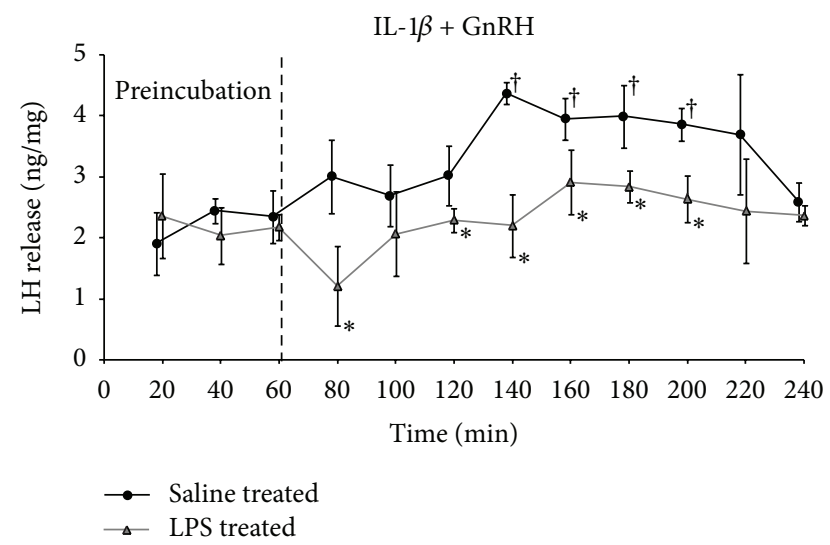

(d)

FIGURE 1: LH release from the AP explants collected from saline- and LPS- treated ewes and incubated in four types of media (control- "pure" medium 199 HEPES (a); GnRH control—medium with GnRH (100 pmol/mL) (b); IL-1 $\beta$-medium with IL- $\beta$ (100 pg/mL) (c); GnRH + IL-1 $\beta$ medium with GnRH $(100 \mathrm{pmol} / \mathrm{mL})$ and IL- $\beta(100 \mathrm{pg} / \mathrm{mL})(\mathrm{d}))$. Each curve represents median \pm SEM release of LH during the consecutive 20 min periods of incubation. ${ }^{\dagger} P \leq 0.01$ (cross indicates values that differ significantly from the median LH release in the same group during preincubation period according to the Mann-Whitney $U$ test) ${ }^{*} P \leq 0.01$ (asterisk indicates values that differ significantly from the salinetreated group according to the Mann-Whitney $U$ test).

LPS-treated compared to saline-treated animals (Figure 3). IL-1 $\beta$ only affected the GnRH-R gene expression in explants collected from LPS-treated animals. The level of GnRH-R mRNA (median exp. $0.43 \pm 0.1)$ was lower $(P \leq 0.01)$ in APs treated with IL-1 $\beta$ and GnRH compared to group incubated only with GnRH (median exp. $0.9 \pm 0.16$ ).

IL-1 $\beta$ did not affect its type I receptor gene expression in AP explants from control- and LPS-treated animals. However, the level of IL-1R1 mRNA was significantly $(P \leq$ 0.01 ) higher in the LPS-treated compared to saline-treated explants (Figure 4).

\section{Discussion}

The results of our ex vivo studies prove that IL-1 $\beta$ is a potent downregulator of LH secretion from the pituitary and suggest that this direct action of interleukin could have a profound effect on the suppression of $\mathrm{LH}$ release occurring during an inflammatory state. However, obtained results are contrary to the previous in vitro experiments. The study performed on the pituitary cells collected from 8 - to 14-month-old wethers showed that both IL- $1 \alpha$ and IL-1 $\beta$ exhibited stimulatory effect on release of LH in vitro [16]. The results of studies carried out on cultured rat pituitary cells showed that IL$1 \beta$ affects the secretory activity of these cells at the dose dependent manner, inhibiting FSH secretion and stimulating LH secretion [17]. Different results of our studies and cited reports could be partially due to different in vitro model. The present ex vivo studies were performed on the AP explants where cells retain the structure of the gland. That allows preserving many of intracellular interaction not available in primary culture of the pituitary. These different in vitro models may be crucial to explain these contradictory data, because the inhibitory action of IL- $1 \beta$ on LH secretion does not have to be an effect of its direct action on gonadotropes. These cells form multiple connections to other pituitary cells such as lactotrophs allowing cell-to-cell communication in the form of adherens junctions [18] and gap junction [19]. The presence of lactotrophs in the incubated AP explants could have a profound impact on the obtained results. It was previously reported that proinflammatory IL- $1 \beta$, IL-6, and tumor necrosis factor $\alpha(\mathrm{TNF} \alpha)$ stimulate prolactin release 


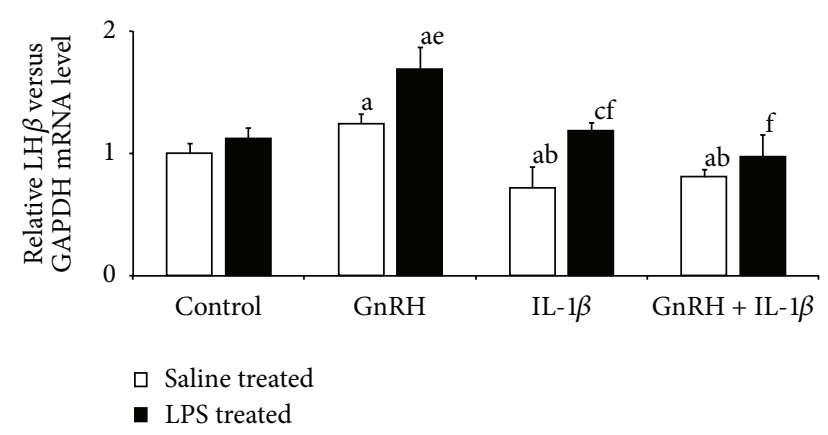

Figure 2: Inhibitory effect of IL- $1 \beta$ on $\mathrm{LH} \beta$ gene expression in the AP explants collected from saline- and LPS-treated ewes and incubated in four types of media (control- "pure" medium 199 HEPES; GnRH - medium with GnRH (100 pmol/mL); IL-1 $\beta$ medium with IL- $\beta(100 \mathrm{pg} / \mathrm{mL})$; GnRH + IL-1 $\beta$ medium with GnRH $(100 \mathrm{pmol} / \mathrm{mL})$ and IL- $\beta(100 \mathrm{pg} / \mathrm{mL}))$. Data are presented as a median value \pm SEM. $a, b, c-P \leq 0.01$ (indicating values that differ significantly from the control, $\mathrm{GnRH}$, and IL-1 $\beta$ groups of saline-treated explants, respectively, according to the MannWhitney $U$ test) and e,f $-P \leq 0.01$ (indicating values that differ significantly from the control and GnRH groups of LPS-treated explants, respectively, according to the Mann-Whitney $U$ test).

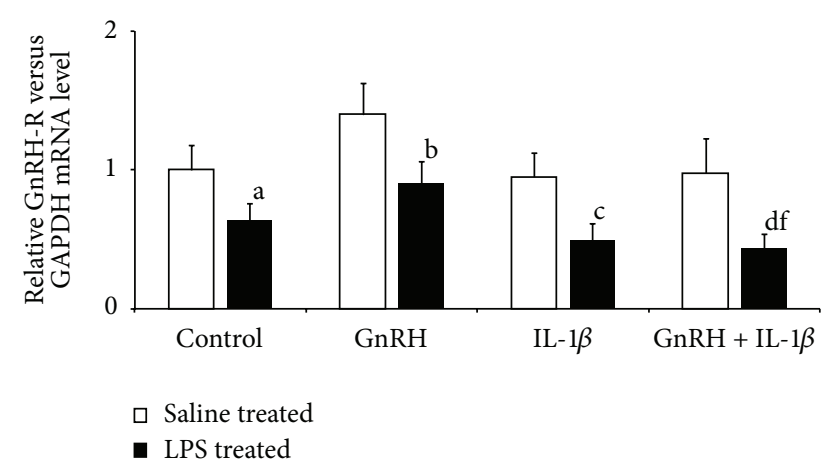

FIGURE 3: GnRH-R gene expression in the AP explants collected from saline- and LPS-treated ewes and incubated in four types of media (control- "pure" medium 199 HEPES; GnRH-medium with GnRH (100 pmol $/ \mathrm{mL})$; IL- $1 \beta$-medium with IL- $\beta(100 \mathrm{pg} / \mathrm{mL})$; $\mathrm{GnRH}+\mathrm{IL}-1 \beta$ medium with GnRH $(100 \mathrm{pmol} / \mathrm{mL})$ and IL- $\beta$ $(100 \mathrm{pg} / \mathrm{mL}))$. Data are presented as a median value \pm SEM. a,b,c,d$P \leq 0.01$ (indicating values that differ significantly from the control, and GnRH, IL- $1 \beta$, GnRH + IL- $1 \beta$ groups of saline-treated explants, respectively, according to the Mann-Whitney $U$ test) and $\mathrm{f}-P \leq$ 0.01 (indicating values that differ significantly from the $\mathrm{GnRH}$ group of LPS-treated explants, respectively, according to the MannWhitney $U$ test).

directly at the rat pituitary gland $[20,21]$. In turn, in vitro study showed that prolactin suppressed LH secretion from cultured pituitary fragments and reduced their responsiveness to $\mathrm{GnRH}$ [22]. This modulatory effect of prolactin on $\mathrm{LH}$ release may occur through the prolactin receptors existing in the gonadotropes. The study performed on sheep showed that pituitary gonadotropes exhibit expression of prolactin receptor enabling a paracrine communication between these cells and prolactin secreting lactotrophs [23]. Therefore, it

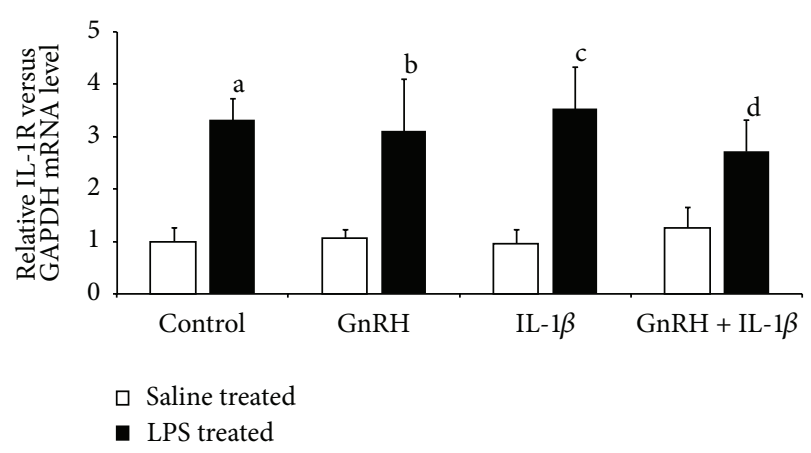

FIGURE 4: Stimulatory effect of LPS pretreatment on IL-1 type I receptor gene expression in the AP explants collected from saline- and LPS-treated ewes and incubated in four types of media (control-"pure" medium 199 HEPES; GnRH-medium with GnRH (100 pmol/mL); IL- $\beta$-medium with IL- $\beta(100 \mathrm{pg} / \mathrm{mL})$; $\mathrm{GnRH}+\mathrm{IL}-1 \beta$ medium with GnRH $(100 \mathrm{pmol} / \mathrm{mL})$ and IL- $\beta$ $(100 \mathrm{pg} / \mathrm{mL}))$. Data are presented as a median value \pm SEM. a,b,c,d$P \leq 0.01$ (indicating values that differ significantly from the control, GnRH, IL- $1 \beta$, and GnRH + IL- $1 \beta$ groups of saline-treated explants, respectively, according to the Mann-Whitney $U$ test).

is possible that IL- $1 \beta$ could suppress $\mathrm{LH}$ release from the AP explants indirectly via induction of prolactin secretion which in turn downregulates LH secretion. The effect of IL-1 $\beta$ on gonadotropes could be also mediated via folliculostellate cells. Folliculostellate cells play an important role as a source of paracrine factors that act locally to modulate pituitary responses to hypothalamic and peripheral signals. One of the paracrine factors that could mediate the IL-1 $\beta$ signal from folliculostellate cells to gonadotropes could be IL-6. It was found that IL- $1 \beta$ indirectly modulates the anterior pituitary cells functioning via stimulating IL-6 production from folliculostellate cells [24]. In turn, IL-6 is known as a modulator of $\mathrm{LH}$ release and gonadotropes response to GnRH-stimulation. However, the effect of IL-6 on pituitary gonadotropes is still ambiguous. The in vitro study showed that IL-6 significantly suppressed GnRH-stimulated $\mathrm{LH}$ release from male rats dispersed pituitaries throughout the dose range but did not influence basal $\mathrm{LH}$ release. In dispersed pituitaries from proestrus female rats IL- 6 had no effect on basal or GnRH-stimulated $\mathrm{LH}$ release [25]. The other study showed stimulatory effect of IL-6 treatment on $\mathrm{LH}$ release from the AP cells in vitro [26].

Our study showed that the pituitaries kept their "memory" of the events triggered by LPS exposure, and this affected AP explants activity during in vitro culture. The analysis of GnRH-R gene expression showed that the transcription of this receptor was lower in the APs from LPS-treated animals compared with explants collected from control one. This fully supports the results of studies carried out on anestrous ewes when an immune stress decreased the amount of GnRH-R mRNA in the AP [1]. The in vivo study performed on ovariectomized ewes showing that bacterial endotoxin decreased the pituitary responsiveness to $\mathrm{GnRH}$ stimulation [27]. It was found that LPS suppressed the amplitude of $\mathrm{LH}$ pulses induced by artificial GnRH pulses. It is hard to 
compare the results of in vivo and in vitro studies. Our results suggest that the used concentration of $\mathrm{GnRH}$ was sufficient to stimulate $\mathrm{LH}$ secretion even in the pituitary cells with decreased expression of GnRH-R. The immune stress decreased GnRH-R mRNA content but did not decrease the pituitary responsiveness to $\mathrm{GnRH}$ stimulation. $\mathrm{GnRH}$ stimulated LH release from explants collected from both LPSand saline-treated animals. The lack of direct connection between the expression of GnRH-R and $\mathrm{LH}$ release from pituitary did not surprise. The study performed on ovariectomized ewes showed that the magnitude and direction of the change in GnRH-R number do not account for the changes in pituitary responsiveness to $\mathrm{GnRH}$ [28]. It is noteworthy that although IL- $1 \beta$ did not affect the GnRH-R gene expression in pituitaries collected from saline-treated ewes, IL-1 $\beta$ affected the GnRH-R mRNA level in explants collected from LPStreated animals. That suggests that inflammatory challenges increased pituitary sensitivity to this cytokine action.

It was found that the potency of IL- $1 \beta$ to affect the LH secretion from pituitary cells seems to be dependent upon the physiological status of the animal before collection of organs. The effect of IL- $1 \beta$ treatment on $\mathrm{LH}$ release was stronger in pituitaries collected from LPS-treated ewes LH release in APs from LPS-treated ewes from the beginning of the experiment. In APs explants collected from control animals, IL- $1 \beta$ only reduced the $\mathrm{GnRH}$-induced release of LH during the first $200 \mathrm{~min}$ of incubation. However, at the end of the experiment, the effect of IL- $1 \beta$ was considerable. The increased sensitivity of pituitary cells collected from LPStreated ewes on IL-1 $\beta$ action seems to result directly from higher expression of IL-1R1 in these cells. It was found that the level of mRNA encoding IL-1R1 in LPS-treated animals was significantly higher compared to saline-treated ewes. The presence of membrane IL-1R1 is essential for a tissue response on IL- $1 \beta$ action. Although IL-1R1-deficient mice show no abnormal phenotype in health and exhibit normal homeostasis, they do exhibit reduced responses to challenge with inflammatory agents [29]. IL-1RI-deficient mice also show an attenuated inflammatory response compared with wild-type mice [30]. The stimulatory effect of immune stress on IL-1R1 expression in the brain tissue has been previously described both in rats and sheep $[31,32]$. However, the effect of endotoxin on the expression of IL-1R1 in the pituitary is not clear. The in vitro study on the mouse AtT-20 pituitary tumor cells showed that direct LPS treatment increases the number of IL-1R1 in a dose-dependent manner [33]. The studies carried out on mice [34] and sheep [31] also reported the stimulating effect of LPS on IL-1R1 mRNA. However, the other studies suggested the inhibitory effect of LPS on IL$1 R 1$ gene expression in the pituitary $[35,36]$, In the present study observed elevation of sheep IL-1R1 mRNA does not have to be an effect of direct action of LPS on pituitary cells. It could be caused by stress of inflammatory response. Stress is a profound upregulator of IL-1R1 expression. The study performed on mice showed that ether-laparotomy stress resulted in a selective increase in pituitary IL-1 receptors. Moreover, an intraperitoneal injection of rat/human CRF mimicked the effects of stress and resulted in a dramatic increase of IL-1 receptor level in the pituitary [35].
In conclusion, the study showed that IL- $1 \beta$ is a potent modulator of LH secretion at the pituitary level. However, the potency of IL- $1 \beta$ to affect the secretory activity of gonadotropes seems to be dependent upon the physiological status of animals. We also discovered that the pituitaries "memory" of the events triggered by LPS exposure seems to result from different expression of cytokines receptors. This suggests that inflammatory stress affects the activity of the pituitary in a prolonged manner, and it could affect its function even for many hours after deprivation of inflammatory signals.

\section{Conflict of Interests}

All authors have declared there is no financial conflict of interests in regard to this work.

\section{References}

[1] A. P. Herman and D. Tomaszewska-Zaremba, "Effect of endotoxin on the expression of GnRH and GnRHR genes in the hypothalamus and anterior pituitary gland of anestrous ewes," Animal Reproduction Science, vol. 120, no. 1-4, pp. 105-111, 2010.

[2] A. P. Herman, K. Romanowicz, and D. Tomaszewska-Zaremba, "Effect of LPS on reproductive system at the level of the pituitary of anestrous ewes," Reproduction in Domestic Animals, vol. 45, no. 6, pp. e351-e359, 2010.

[3] D. Refojo, P. Arias, J. A. Moguilevsky, and C. Feleder, "Effect of bacterial endotoxin on in vivo pulsatile gonadotropin secretion in adult male rats," Neuroendocrinology, vol. 67, no. 4, pp. 275281, 1998.

[4] P. Igaz, R. Salvi, J. P. Rey, M. Glauser, F. P. Pralong, and R. C. Gaillard, "Effects of cytokines on gonadotropin-releasing hormone $(\mathrm{GnRH})$ gene expression in primary hypothalamic neurons and in GnRH neurons immortalized conditionally," Endocrinology, vol. 147, no. 2, pp. 1037-1043, 2006.

[5] S. Rivest and C. Rivier, "The role of corticotropin-releasing factor and interleukin-1 in the regulation of neurons controlling reproductive functions," Endocrine Reviews, vol. 16, no. 2, pp. 177-199, 1995.

[6] M. J. Yoo, M. Nishihara, and M. Takahashi, "Involvement of prostaglandins in suppression of gonadotropin-releasing hormone pulse generator activity by tumor necrosis factor- $\alpha$," Journal of Reproduction and Development, vol. 43, no. 2, pp. 181187, 1997.

[7] M. Feldmann and J. Saklatvala, "Proinflammatory cytokines," in Cytokine Reference, vol. 1, pp. 291-305, 2001.

[8] A. P. Herman, T. Misztal, K. Romanowicz, and D. TomaszewskaZaremba, "Central injection of exogenous IL-1 $\beta$ in the control activities of hypothalamic-pituitary-gonadal axis in anestrous ewes," Reproduction in Domestic Animals, vol. 47, no. 1, pp. 4452, 2012.

[9] S. S. Kang, S. R. Kim, S. Leonhardt, H. Jarry, W. Wuttke, and K. Kim, "Effect of interleukin-1 $\beta$ on gonadotropin-releasing hormone $(\mathrm{GnRH})$ and $\mathrm{GnRH}$ receptor gene expression in castrated male rats," Journal of Neuroendocrinology, vol. 12, no. 5, pp. 421-429, 2000.

[10] O. Ebisui, J. Fukata, T. Tominaga et al., "Roles of interleukin$1 \alpha$ and $-1 \beta$ in endotoxin-induced suppression of plasma gonadotropin levels in rats," Endocrinology, vol. 130, no. 6, pp. 3307-3313, 1992. 
[11] E. Ban, C. Marquette, A. Sarrieau et al., "Regulation of interleukin-1 receptor expression in mouse brain and pituitary by lipopolysaccharide and glucocorticoids," Neuroendocrinology, vol. 58, no. 5, pp. 581-587, 1993.

[12] P. Parnet, D. L. Brunke, E. Goujon et al., "Molecular identification of two types of interleukin-1 receptors in the murine pituitary gland," Journal of Neuroendocrinology, vol. 5, no. 2, pp. 213-219, 1993.

[13] R. Stupnicki and A. Madej, "Radioimmunoassay of LH in blood plasma of farm animals," Endokrinologie, vol. 68, no. 1, pp. 6-13, 1976.

[14] R. Rasmussen, "Quantification on the LightCycler," in Rapid Cycle Real-Time PCR Methods and Applications, S. Meuer, C. Wittwer, and K. Nakagawara, Eds., Berlin, Germany, 2001.

[15] M. W. Pfaffl, A. Tichopad, C. Prgomet, and T. P. Neuvians, "Determination of stable housekeeping genes, differentially regulated target genes and sample integrity: BestKeeper-excelbased tool using pair-wise correlations," Biotechnology Letters, vol. 26, no. 6, pp. 509-515, 2004.

[16] T. D. Braden, C. Fry, and J. L. Sartin, "Effects of interleukins on secretion of luteinizing hormone from ovine pituitary cells," American Journal of Veterinary Research, vol. 59, no. 11, pp. 1488-1493, 1998.

[17] T. Murata and S. Y. Ying, "Effects of interleukin- $1 \beta$ on secretion of follicle-stimulating hormone (FSH) and luteinizing hormone (LH) by cultured rat anterior pituitary cells," Life Sciences, vol. 49, no. 6, pp. 447-435, 1991.

[18] E. Horvath, K. Kovacs, and C. Ezrin, "Functional contacts between lactotrophs and gonadotrophs in the rat pituitary," IRCS Medical Science, vol. 5, no. 11, p. 511, 1977.

[19] I. Morand, P. Fonlupt, A. Guerrier et al., "Cell-to-cell communication in the anterior pituitary: evidence for gap junctionmediated exchanges between endocrine cells and folliculostellate cells," Endocrinology, vol. 137, no. 8, pp. 3356-3367, 1996.

[20] M. Yamaguchi, K. Koike, Y. Yoshimoto, H. Ikegami, A. Miyake, and O. Tanizawa, "Effect of TNF- $\alpha$ on prolactin secretion from rat anterior pituitary and dopamine release from the hypothalamus: comparison with the effect of interleukin-1 $\beta$," Endocrinologia Japonica, vol. 38, no. 4, pp. 357-361, 1991.

[21] J. E. Beach, R. C. Smallridge, C. A. Kinzer, E. W. Bernton, J. W. Holaday, and H. G. Fein, "Rapid release of multiple hormones from rat pituitaries perifused with recombinant interleukin-1," Life Sciences, vol. 44, no. 1, pp. 1-7, 1989.

[22] C. Y. Cheung, "Prolactin suppresses luteinizing hormone secretion and pituitary responsiveness to luteinizing hormonereleasing hormone by a direct action at the anterior pituitary," Endocrinology, vol. 113, no. 2, pp. 632-638, 1983.

[23] D. J. Tortonese, J. Brooks, P. M. Ingleton, and A. S. Mcneilly, "Detection of prolactin receptor gene expression in the sheep pituitary gland and visualization of the specific translation of the signal in gonadotrophs," Endocrinology, vol. 139, no. 12, pp. 5215-5223, 1998.

[24] L. M. Bilezikjian, A. M. Leal, A. L. Blount, A. Z. Corrigan, A. V. Turnbull, and W. W. Vale, "Rat anterior pituitary folliculostellate cells are targets of interleukin-1 $\beta$ and a major source of intrapituitary follistatin," Endocrinology, vol. 144, no. 2, pp. 732740, 2003.

[25] S. H. Russell, C. J. Small, S. A. Stanley, S. Franks, M. A. Ghatei, and S. R. Bloom, "The in vitro role of tumour necrosis factoralpha and interleukin- 6 in the hypothalamic-pituitary gonadal axis," Journal of Neuroendocrinology, vol. 13, no. 3, pp. 296-301, 2001.
[26] B. L. Spangelo, A. M. Judd, P. C. Isakson, and R. M. MacLeod, "Interleukin-6 stimulates anterior pituitary hormone release in vitro," Endocrinology, vol. 125, no. 1, pp. 575-577, 1989.

[27] C. Y. Williams, T. G. Harris, D. F. Battaglia, C. Viguié, and F. J. Karsch, "Endotoxin inhibits pituitary responsiveness to gonadotropin-releasing hormone," Endocrinology, vol. 142, no. 5, pp. 1915-1922, 2001.

[28] I. J. Clarke, J. T. Cummins, M. E. Crowder, and T. M. Nett, "Pituitary receptors for gonadotropin-releasing hormone in relation to changes in pituitary and plasma gonadotropins in ovariectomized hypothalamo/pituitary-disconnected ewes. II. A marked rise in receptor number during the acute feedback effects of estradiol," Biology of Reproduction, vol. 39, no. 2, pp. 349-354, 1988.

[29] C. A. Dinarello, "The IL-1 family and inflammatory diseases," Clinical and Experimental Rheumatology, vol. 20, no. 5, supplement 27, pp. S1-S13, 2002.

[30] M. D. Josephs, C. C. Solorzano, M. Taylor et al., "Modulation of the acute phase response by altered expression of the IL-1 type 1 receptor or IL-1ra," American Journal of Physiology, vol. 278, no. 4, pp. R824-R830, 2000.

[31] A. P. Herman, T. Misztal, A. Herman, and D. TomaszewskaZaremba, "Expression of interleukin (IL)- $1 \beta$ and IL-1 receptors genes in the hypothalamus of anoestrous ewes after lipopolysaccharide treatment," Reproduction in Domestic Animals, vol. 45, no. 6, pp. e426-e433, 2010.

[32] A. M. Lynch, C. Walsh, A. Delaney, Y. Nolan, V. A. Campbell, and M. A. Lynch, "Lipopolysaccharide-induced increase in signalling in hippocampus is abrogated by IL-10-a role for IL1 $\beta$ ?" Journal of Neurochemistry, vol. 88, no. 3, pp. 635-646, 2004.

[33] C. Kumagai, T. Takao, R. Matsumoto, K. Asaba, and K. Hashimoto, "Modulation of interleukin-1 receptors followed by endotoxin lipopolysaccharide treatment in the mouse AtT-20 pituitary tumor cell line," NeuroImmunoModulation, vol. 10, no. 5, pp. 310-316, 2003.

[34] M. M. Gabellec, R. Griffais, G. Fillion, and F. Haour, "Interleukin-1 receptors type I and type II in the mouse brain: kinetics of mRNA expressions after peripheral administration of bacterial lipopolysaccharide," Journal of Neuroimmunology, vol. 66, no. 1-2, pp. 65-70, 1996.

[35] T. Takao, K. Hashimoto, and E. B. De Souza, "Modulation of interleukin-1 receptors in the brain-endocrine-immune axis by stress and infection," Brain, Behavior, and Immunity, vol. 9, no. 4, pp. 276-291, 1995.

[36] T. Takao, H. Nakata, C. Tojo et al., "Regulation of interleukin-1 receptors and hypothalamic-pituitary-adrenal axis by lipopolysaccharide treatment in the mouse," Brain Research, vol. 649, no. 1-2, pp. 265-270, 1994. 


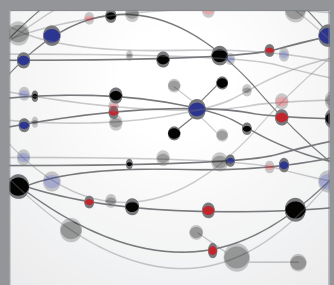

The Scientific World Journal
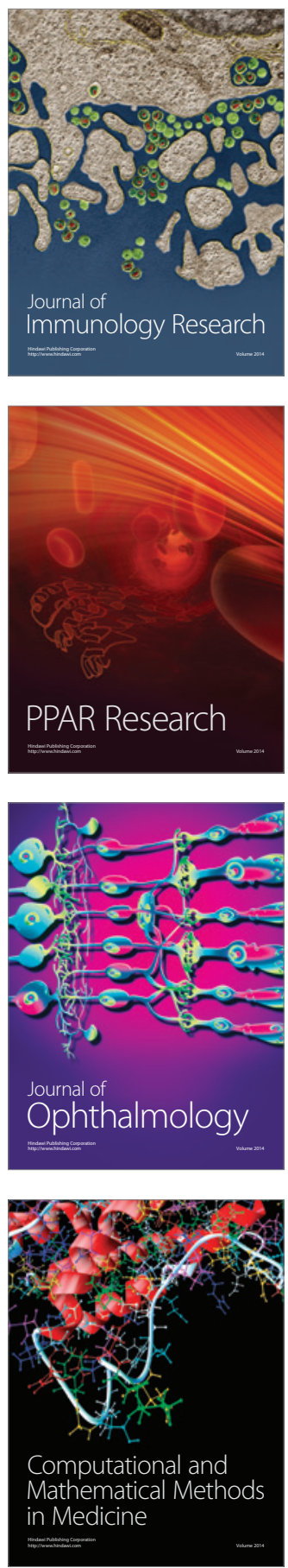

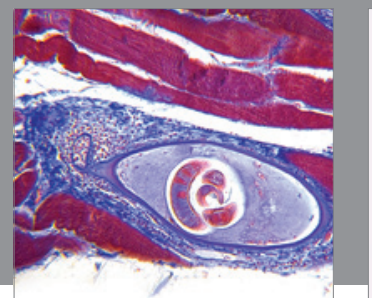

Gastroenterology

Research and Practice
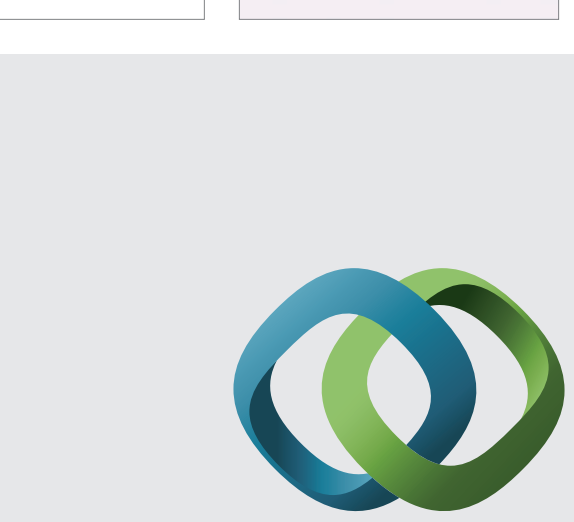

\section{Hindawi}

Submit your manuscripts at

http://www.hindawi.com
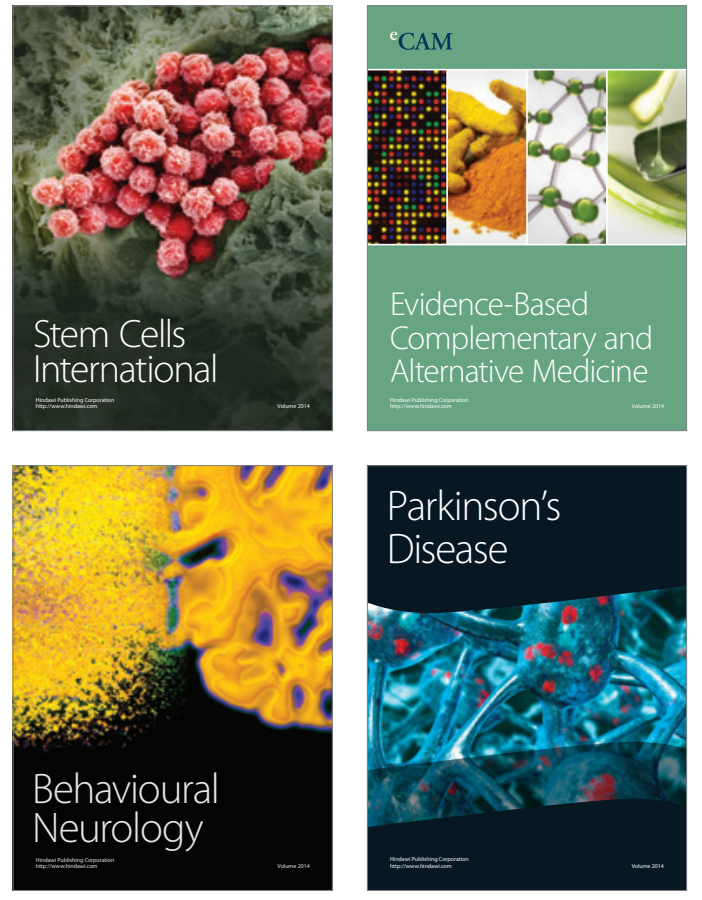
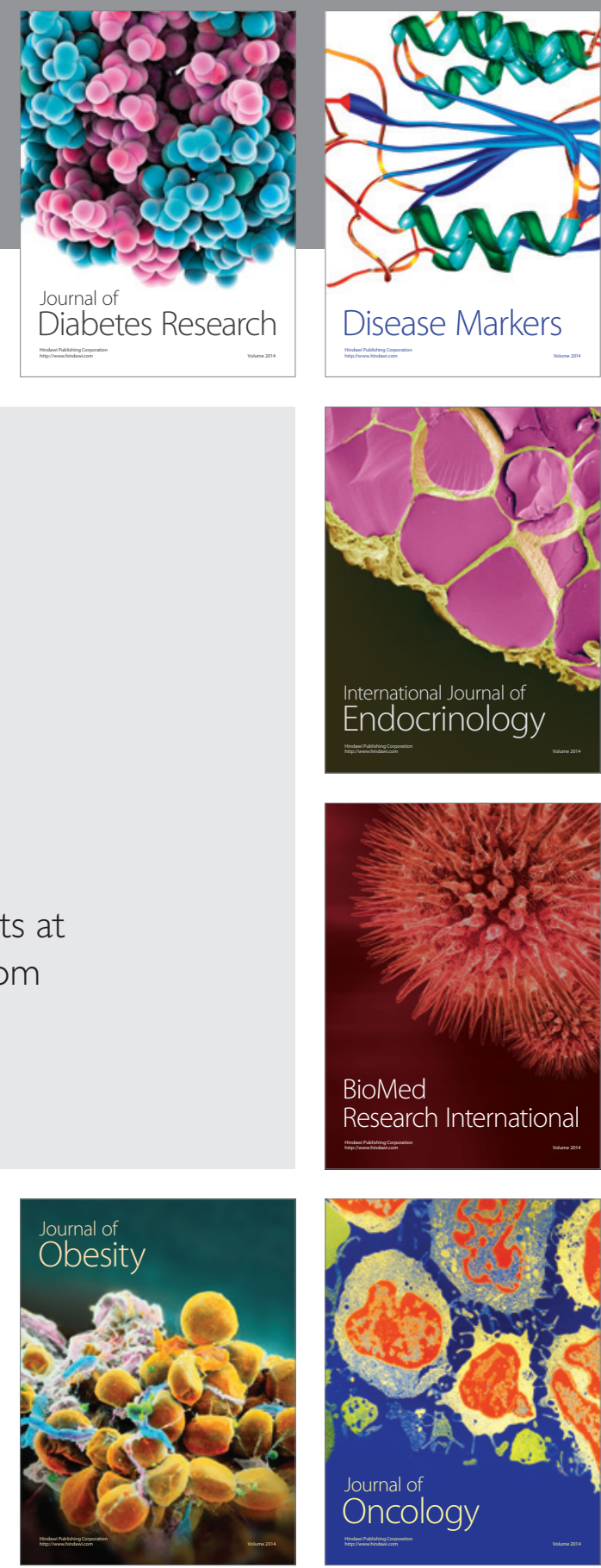

Disease Markers
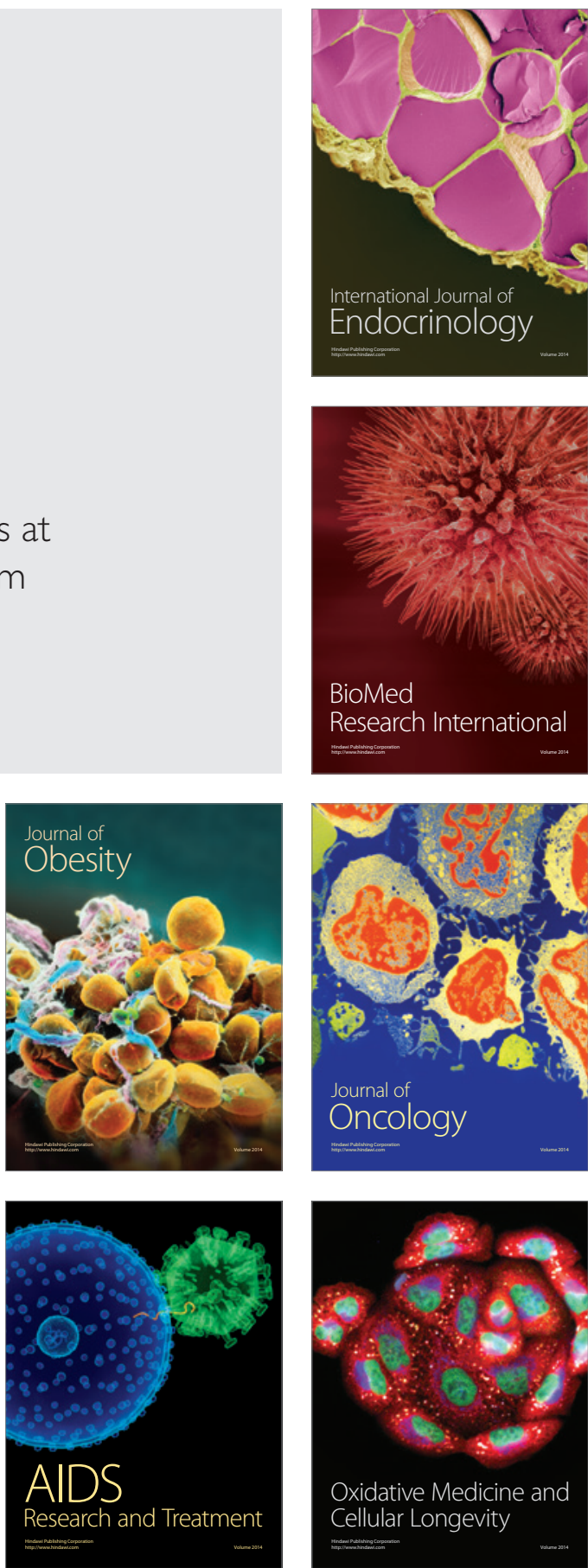